\title{
Performance of Active Customers Number PT Pegadaian Indonesia Period 2011-2016
}

\author{
${ }^{1}$ ACHMAD DAENGS GS, ${ }^{2}$ DIANA ZUHROH \\ 1,2_Fakultas Ekonomi Universitas 45 Surabaya, Jl. Mayjen Sungkono No. 106 Surabaya - 60256 \\ ${ }^{1}$ bumigora80@gmail.com; ${ }^{2}$ dianazuhroh5@gmail.com
}

\begin{abstract}
The objective of this study to analyze the consequences of active customers number, operational offices, loans granted to net income at PT Pegadaian. Data were quantitative sourced from secondary data taken from official website of PT Pegadaian Indonesia in the form of annual financial statements period 2011-2016 (Central Biro Statistic). Data analysis technique used in this research is Structural Equation Model (SEM) analysis with Smart Partial Least Square (PLS) tool. The results of this study indicate that: (1) number of active customers has an insignificant effect on net income; (2) the operational office has a significant positive effect on net income; (3) loans granted has significant and positive effect on net income. In general, financial statement consists of balance sheet, profit and loss and report of financial position changes. Balance sheet shows total assets, debt and capital of inventory on a certain date, financial ratios are the most popular tool for analyzing financial statements.
\end{abstract}

Keywords: Number of Active Customers, Operational Offices, Loans granted.

\section{Introduction}

Perum Pegadaian is the solely non-bank financial institutions under the Ministry of Finance Republic of Indonesia. The ultimate goal of pawnshops is to cope with the need for money-stricken societies not to fall into the hands of moneymakers or moneylenders or relatively high interest-rate lenders.

In the life of society, Pawnshop is used as a solution to earn money easily, namely by mortgaging goods that have economic value such as gold, electronic goods, jewelry, and others. Duration of collecting the mortgaged goods depends on how much money has been earned by a pawnbroker, as well as paying the interest that has been determined.

According to (Daengs, GS et al., 2017), The financial analysis of the alternative performance techniques of financial statements that reflect the actual performance of the company.

As an institution of State Owned Enterprises (BUMN), PT Pegadaian (Persero) also assumes responsibility as a development agent. To that end, Pegadaian continues to strengthen its commitment support the Governmental programs in the context of national economic advance.

The presence of a pawn business has helped the government's role in financial inclusion by helping middle and low-income communities gain access to finance and payment facilities. In addition, mortgage business also becomes a funding solution for the community, breaking the practice of debt bondage and avoid the moneylenders' circle.

In 2016, the mortgage industry in Indonesia has entered a new phase. The issuance of POJK No.31/POJK.05/2016 concerning Pegadaian is expected to make mortgage industry not to mention "wild." Through the regulation, OJK (Moneter Service Authority) regulates the form of legal entity, capital, business licensing requirements and procedures. In addition it also regulates the permitted business activities and implementation of some business activities based on sharia principles.

With the POJK, the mortgage industry is expected to contribute and increase financial inclusion for middle and lower society as

Received: April 16, 2018, Revision: July 30, 2018, Accepted: December 6, 2018

Print ISSN: 0215-8175; Online ISSN: 2303-2499. DOI: http://dx.doi.org/10.29313/mimbar.v34i2.3682.397-405

Accredited B based on the decree No.040/P/2014, valid on February, 18, 2014 until February, 18, 2019. Indexed by DOAJ, Sinta, IPI 
well as micro, small and medium enterprises (SMEs). The presence of more organized and healthy pawnshops in performance is believed to facilitate public access to loans, where pawnshops become one of the financing alternatives to society in the financial services industry. The objective of this study to settle the consequences of customer number, loans granted, and office operations of net profit PT Pegadaian Indonesia Period 2011-2016.

Every company that has implemented company governance pours the activities results that have been implemented in the reports form. Among the reports made are financial statements containing company financial information that allows managers or analysis to review performance of the company. The most common form of financial information of an enterprise is a set of financial statements issued according to the public accounting profession guidelines (the common accounting principles).

Financial ratios are the most popular tool for analyzing financial statements so it can know the condition or financial performance of the company. From analysis results can be known liquidity, solvency, activity and profitability, because ratio analysis using financial data taken from balance sheet and income statement. Below is the definition of financial statements according to (Riyanto, 2013), namely: "Financial Statements, provides an overview of the financial condition of a company, where balance sheet reflects assets values, debt and equity at a certain time, and income statements reflect the results achieved during a given period typically cover a period of one year."

Financial statements are designed for decision makers, both inside and outside the company. The contents of the report is about the company's financial position within a certain period. The financial statements are the end result of the financial process and are the most important part in conveying economic information of a company to the parties in need, according to (Daengs, GS, Mahjudin, 2014). Costs of quality were reported to make management aware of the magnitude of the cost of quality and provide the basis for measuring the impact of quality can be used in the show because of the quality problems in the unit value that is easily understood by management.

In general, financial statement consists of balance sheet, profit and loss and report of financial position changes. Balance sheet shows total assets, debt and capital of inventory on a certain date. The profit and loss statement shows results of the company has achieved as well as the costs incurred during a certain period and the statement of changes in financial position indicates source and use of funds or reasons causing the change in the company's capital position. But in practice often included other groups that help to obtain further explanation. For example, changes in working capital reports, use sources of the cash or cash flow statements, reports of changes in gross profit, production cost reports and other lists.

Regarding the meaning of financial statements there are some opinions expressed by the experts. "The financial statements is to provide an overview of the financial situation of company, in which the balance sheet reflects the value of assets, liabilities and equity at a certain period and the income statement reflects the results that have been achieved during the certain period", according to (Eliana, 2009).

The financial statement preparation is made periodically and period used is annual, beginning on January 1 and ending on 31 December. The term accounting period is often also referred to as the book year. Although the accounting period used is annual but management can still prepare financial statements in the shorter period which is often also referred to as the term of interim report.

Analysis of financial statements made is intended to add to existing information in a financial report. The complete use of financial statement analysis can be put forward as follows (Harahap, 2012):

Able to dig invisible information visible from
a financial statement, to know the mistakes
contained in financial statements, to rank
companies according to certain criteria
already known in the business world, to
compare situation of the company with other
similar companies within a certain period,
Understanding financial situation and condition
experienced by the company, both financial
position, business results, financial structure
and so forth, used to predict what potentials
may be experienced by companies in the
future.

The benefits of financial statements are closely related to the financial statements purposes themselves. The benefits of the financial statements themselves are (Harahap, 2012): Financial statements can be used as a form of management accountability to the owner, because financial statements are 
MIMBAR, Vol.34 No 2 ${ }^{\text {nd }}$ (December) 2018 pp. 397-405

useful to see financial condition as well as a picture of the results or development of the company.

Financial reports can be used by management as a means to correct errors that occur. Minimize the costs that should not be issued without having to reduce the company's performance and quality of the resulting product so that profits can be improved by the increase of sales and efficiency in each part of the company.

It is useful to conduct an assessment of the performance of each individual within the company that has exercised its authority and responsibility. Financial statements can serve as a tool of change so that the company can achieve the desired results.

Financial statements can be used as a means of communication between companies with interest parties to the company.

Of all the definitions about financial statements above, which will be discussed is about the balance sheet and income statement (Harahap, 2012).

Balance sheet is one of the main parts of financial statements prepared systematically, about financial position at a certain time. From the balance sheet can be known how far the company can finance all business activities through capital and debt in the form of assets. Thus balance sheet consists of:assets, debt, capital.

In the balance sheet presentation can be divided into two forms (Harahap, 2012), namely:

Staffel Balance or Report Form: The balance sheet is reportedly one page vertical. The above is total assets and liabilities post and capital post presented underneath, and Skontro Balance or Account Form; Assets are presented on the left and liabilities and capital are placed on the right so that the presentation is next to each other.

Income statement is a report describing operations result of the business activity over a period of time. The essential elements of the income statement (Harahap, 2012) are comprised of:

Sales or main income, principal income of a trading company, service company or industrial enterprise shall be the proceeds of the sale of goods and services to the buyer or subscription, business costs, business costs arise in connection with the sale or marketing of goods or services of such companies, cost of Goods Sold, in industrial companies the cost of goods sold includes the costs of raw materials, labor and indirect factory costs in the goodsmaking process. While services cost consists of the costs of materials, labor and other materials used to produce services, non-operating income and expenses, earnings gained and expenses incurred which have no relation to the principal business of the enterprise. For example: interest income, dividend income, commission income, interest cost, rental fee and others, finance expenses in conducting business, for example interest paid to creditors and dividends paid to preferred shareholders.

Financial statement analysis is useful to know financial position that has been achieved by the company in a certain period. Many parties have an interest in the financial statements to be used as a reference in making economic policy. The financial statements users and their uses can be explained as follows (Riyanto, 2013):

Owner of the Company, for the owners / shareholders the financial statements are intended to Assess the achievements or results obtained by management, Knowing outcome of the dividend to be received, Assess the company's financial position and its growth, Know the value of stock and earnings per share, As a basis for predicting corporate conditions in the future, As a basis to consider adding or reducing investment.

Company Management, for the financial company's management report it is useful to Measures the management accountable of the company for owners or shareholders, Measures the cost level of each company's operating activities, divisions, section or specific segments, Measures the level of efficiency and profitability of a company, division, section or segment, Assess the work of individuals who are given tasks and responsibilities, As a consideration in determining whether new policy should be taken or not, Comply with the provisions of laws, regulations, articles of association, capital markets and other regulatory agencies.

Investors, for investors the financial statements are intended to Assess the company's financial condition and results of operations, Assess the possibility of investing in the company, Assess the possibility of attracting funds/investments from the company, Become the basis for predicting the company's financial condition in the future.

Company Employees, for financial report employees it is useful to know the ability of companies to provide wages and salaries and other social security to them, especially in the intensive policies and bonuses they can receive in return for their participation in achieving company goals. 
Capital Market Analyst, for the capital market always conduct a sharp and complete analysis of the financial statements of companies that go public or potentially enter the capital market. Analysts want to know the company's value, strength and financial position. Is it worth advised to buy its shares, sold or maintained. This information will be presented to both individual and institutional investors.

Assessment conducted by the bank in accordance with the prudential principles in order to reduce the risk that will arise in the future. The embodiment of prudential principles in the framework of lending is reflected in the criteria called "The Five C's of Principle of Credit Analysis" (Sembiring, 2012). The explanation analysis of $5 C$ is as follows, Character, which means the individual, nature, habits of the debtor (party owed) is very influential on the credit provision.

The creditor check whether the debtor is in the DOT List (Blamable Person List). For creditor also can examine his or her personal data and information from business circle. Information about business circle can be obtained after the suppliers and customers of the borrower.

Also obtained from Central Bank information, but not easily obtained by the public, because information only can be accessed by the bank officers using passwords and computers connected the Central Bank by online. In addition to examining formal documents accompany the credit, also should be known that the track record of credit applications from various that can be used as a reference by bank credit analyst, Capacity, it is related to the debtor's ability to reimburse a loan.

To appraise it, the lender can examine the debtor's ability in areas of management, finance, marketing, and others, Capital, regarding the capital amount belong to the debtor or find out how much capital invested by the debtor in his business, the creditor assesses debtor's capital. The higher capital invested, so the debtor will be considered as serious in running the deal.

Apart from the assessment through $5 \mathrm{C}$ analysis method in the bank assessment known as 7P19 assessment method are as follows: Personality, assessing customer from his or her personality or daily behavior as well as past. In addition it also includes attitudes, emotions, behavior, and actions of customers in the face of problems, Party, classify customer into classification or certain groups based on capital, loyalty, and character, so that customers will get different facilities.

PT. Pegadaian established on the Government grand aspiration help wideranging community in need of funding solutions, prevent debt bondages, loan sharks and other unreasonable liabilities to improve the people welfare and support the Government's program in economic and national development.

In its journey, PT. Pegadaian is not only a financing institution, but has developed as an integrated business solution for community through various products and services provided, namely mortgage and fiduciary financing for people who need liquidity (funding), gold investment products easily and safe for people with excess liquidity, and various services products (remittance \& payment) for people who need financial transaction acceleration services.

Pegadaian has the objectives and purpose to conduct business activities in the area of mortgage and fiduciary, either conventionally or sharia, and further services in the finance field consistent with the stipulation of legislation. These dealing activities aim give assistance for lower middle income, micro, small and medium enterprises, and optimize the sources utilization of Pegadaian by implementing principles of limited liability company. To realize these purposes and objectives. (Daengs GS, 2018)

Pegadaian conducts business actions as follows: Main business activities: Loans disbursement under the mortgage law include the securities pawning; Loans disbursement under fiduciary guarantee; Deposit services, appraise services, certificates, and trading of priceless metals and gemstone.

Other business dealing: Money transfer, payment transaction, and loan administration; Optimize the sources utilization of Pegadaian. According to (Mahjudin, 2017). The complexity of the development occurred causing no one of the proper development theory to be applied to a country.

As an integrated business solution primarily mortgage-based continually as a market leader and finance micro-based always come into the best in the middle class.

Pegadaian can provide solutions to 
funding needs through product financing, excess funds with gold investment products, and the need for accelerated financial transactions through online multipayment and remittance products.

Offer financing as the fastest, easiest, safe and constantly deliver the guidance to the medium business and encourage economic advance. Make sure the equity of services and infrastructure by providing convenience and suitability all over the Pegadaian and prepare to be a regional player and keep on the primary choice of the people. Support the government in improving the middle-class welfare and carry out the other efforts to optimize Pegadaian resources.

During this time, analysis of financial statements is more directed at the financial ratios that include liquidity ratios, asset management, debt management and profitability ratios. Unfortunately, financial ratios also have weaknesses because management financial statements to perform Window Dressing technique. The financial statements became as if reflecting the company in better condition but the real condition was not like that, according to (Rizaldy, MR, et al 2017).

Based on above definition, it can be concluded that the financial report is a report that provides financial overview or condition of a PT. Pegadaian that can show the total assets, liabilities and capital expressed in terms of the balance sheet and the yield during the accounting period, which is expressed in the income statements, where the number is obtained through the process of recording financial transaction, in order to account for the tasks assigned to management by the owner of the PT. Pegadaian, according to (Rizaldy, MR, et al 2017).

The complete financial statement usually includes of balance sheet, income statement, and statement of changes in financial position (which may be expressed in various ways, for example, a cash flow statement or fund flows statement), notes and other statements and explanatory material that are an integral part of the financial statement.

Besides, it also includes schedules and additional information relating to the statement, for example, the financial information of industry segments and geographical as well as the disclosure of the effect of price changes, according to (Rizaldy,
$M R$, et al 2017).

\section{Research Method}

According Hermawan (2013) data source can be divided into primary data and secondary data. The data type in this study is secondary data is data which is historical data structure about variables that have been collected and compiled previously by other parties (Hermawan, 2013). Quantitative data is data used in this study, obtained from the official site of PT Pegadaian Indonesia (Pegadaian.co.id) in the form of annual financial statements during period 20112016.

Data collection methods in this study is to use a document in the form of financial statements. Financial statements obtained through downloading financial statement data on the official website of PT Pegadaian Indonesia (www.pegadaian.co.id). This research data includes company data in the form of annual financial report period 20112016.

Data analysis is the process of simplifying data into easier form to be read and implemented. The analysis technique chosen to analyze data and test the hypothesis in this research is The Structural Equation Model (SEM).

To answer the hypothesis used Partial Least Square (PLS). According (Sembiring, $S$, 2012) calculations performed using Smart Partial Least Square (PLS) tool, due to the multi-path shape and model used in the Reflective form.

Calculation model is done by using Smart PLS tool because in this research have multi-path relationship and formative and reflective forms. In addition, sampling is less than 100 respondents.

Formative model is a model that shows the direction of the relationship from indicator to latent variable. The reflective model is a model showing relationship of the latent variable to its indicator.

Sample in this research is chosen by purposive sampling that is sample determination technique with certain consideration (Sugiono, 2014). So in accordance with the previous explanation researchers consider the entry into the sample is the annual financial report of PT Pegadaian Indonesia (Pegadaian.co.id) during the year 2011-2016. 
Table 1

Definition of Operational Variable

\begin{tabular}{|c|c|c|c|}
\hline $\begin{array}{l}\text { Definition of Measured } \\
\text { Operational Variables }\end{array}$ & Indicators & Scale & $\begin{array}{l}\text { Data } \\
\text { source }\end{array}$ \\
\hline $\begin{array}{l}\text { Dependent variable: } \\
\text { Net profit }\end{array}$ & Number of net profit received by PT. Pegadaian & Ratio & Secondary \\
\hline $\begin{array}{l}\text { Independent variable: } \\
\text { Number of active customer }\end{array}$ & Number of customer who receive loan & Ratio & Secondary \\
\hline Number of operational office & $\begin{array}{l}\text { Number of PT. Pegadaian office which operating } \\
\text { in whole Indonesia }\end{array}$ & Ratio & Secondary \\
\hline Loans granted & Jumlah pinjaman yang diberikan & Ratio & Secondary \\
\hline Source : Processed Data, 2016. & & & \\
\hline
\end{tabular}

\section{Inner Model (Structural Model) Definition of Operation}

In Table 1 explained the definition of independence variable, number of active customer, number of operational office, loans granted and independence variable net profit.

Analysis result of structural model conformity built showed the conclusion that whole model has "relevant" to explain researched variables and their effect on respective variables. Calculation $f \mathrm{Q}^{2}$ value gained value of 0,986 or exceeding the critical limit 0,5 thus structural model has expressed fit and properly.

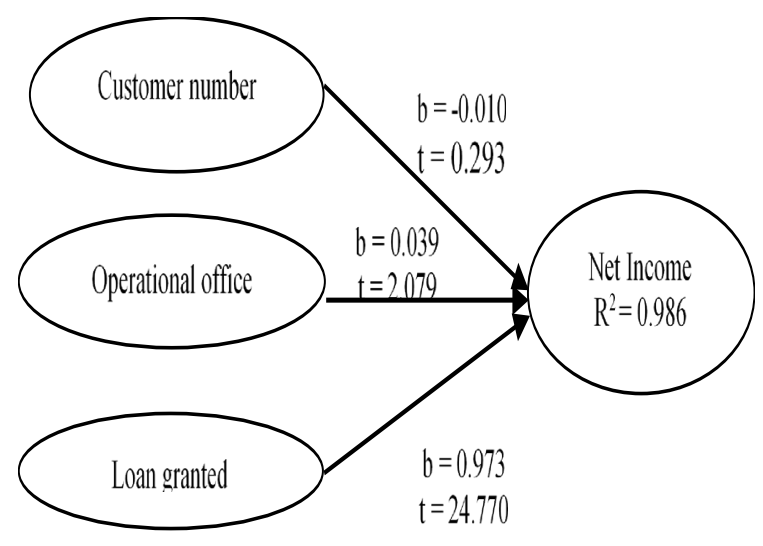

Figure 1. Inner PLS Model

Source: Is the result of analysis using PLS

There are 3 exogenous variables in the inner model studied, ie Number of Active Customers, Operational Offices, Loans Granted while endogenous variables in the inner model studied are Net Profit. In the equation model with endogenous Net Profit the $\mathrm{R} 2$ value reaches 0.986 . This means that Net Income can be explained by the Number of Active Customers, Operations Offices, Loans granted reached $98.6 \%$.
The result of Q2 achieved is 0.986 which is in the range $0,66-1,00$, so it can be said that the model is a "Good" model (figure 1).

\section{Result of Hypothesis \\ Hypothesis Test $1\left(\mathbf{H}^{\mathbf{1}}\right)$}

The first hypothesis in the study is unproved true, because data analysis result shows that value of 0.293 which means smaller than 1.96 , so it can be said that the number of Active Customers have an insignificant effect on net income has 0.010 with a negative direction.

\section{Hypothesis $2\left(\mathrm{H}^{2}\right)$}

The second hypothesis in the study proved true, because data analysis result showed that value of 2.079 which means greater than 1.96 , so it can be said that the Operational Office has a significant positive on net income with a big effect of 0.039 which means the more operational office which operate will further increase net income.

\section{Hypothesis $3\left(\mathrm{H}^{3}\right)$}

The third hypothesis in the research proved true, because data analysis result shows that $t$-value of 24.770 which means greater than 1.96 , so it can be said that Loans granted a significant and positive on net income with a big effect of 0.973 which means more loans granted will further increase net income.

\section{Discussion}

From the data analysis built the results showed that the number of active customers have no significant effect on net income in PT Pegadaian. These results indicate that an increase in the number of active customers will not necessarily be able to increase net 
income in PT Pegadaian, which the existence of the number of customers has not a significant impact to increase income of PT Pegadaian. Both variables have a negative relationship direction, in which the number of active customers has increased but in the achievement of profit there is a decline from 2013 to 2014. This is because the number of active customers who are growing more but not necessarily all customers make timely payments, so also affecting net income that indicates a decline.

The results in this study are not in line with (Borolla, 2013) which proves that the number of customers has positive and significant effects on the increase of profits earned. Similarly, (Suryanti, 2006) who found that the increase in the customers number will have a significant positive effect on lending in Perum Pegadaian Syaria Branch Dewi Sartika and Perum Pegadaian in DIY. Increased lending in turn will influence the increase of corporate profits.

Data analysis results showed that there is significant effect of the operational office to increase net income in PT Pegadaian. The direction of relationship between two variables is positive, which means there is a direct relationship between operational office and the net profit or in other words the more operational offices of PT Pegadaian operated it will be able to reach much more customers, so it will be able to increase net income. The operational office is like a distribution channel that serves to provide community convenience in fulfilling their needs. Operational office also functions as the development or innovation of Pegadaian's products and services, in addition to business development also aimed at the creation of more efficient business processes.

Operations Office also serves to educate the public about the meaning and understanding of financial transaction services, especially products and services provided by Pegadaian. Once the public is aware of the level of literacy, the Pegadaian has solved the financial services need for community in three core services: 1 ) financing products to meet the people's needs for funding / liquidity, 2) gold investment products to facilitate over-funding / liquidity communities, and 3) other miscellaneous services (remittance and payment) to accelerate financial transaction services.

The analysis results also indicate that the amount of loan granted significantly affect the net income of PT Pegadaian. Direction of the relationship between two variables indicates a positive direction which means the higher the loan will increase the net profit. The presence of the mortgage business has helped the government's role in financial inclusion by helping middle and low-income communities gain access to money and payment facilities. In addition, the mortgage business also solicits funding for the community, breaks the practice of debt bonding and avoids the moneylenders' circle. With the POJK, the mortgage industry is expected to contribute the increase of financial inclusion for lower middle class and also micro, small and medium enterprises (SMEs).

The presence of more organized and healthy mortgage companies in performance is believed to facilitate public access to loans, where mortgage companies are one of the financing alternatives to society in financial services industry. The Pegadaian fully supports regulators' efforts to organize the mortgage industry in Indonesia through the issuance of the Financial Services Authority Regulation. The issuance of POJK No. 31 / POJK.05 / 2016 concerning Pegadaian Enterprises is expected to make the mortgage industry not to mention "wild". Through the regulation, OJK regulates the form of legal entity, capital, business licensing requirements and procedures.

At last, the issuance of the regulation will benefit and protect the public from unfair mortgage deals. In addition, with the issuance of POJK is also a challenge as well as motivation for Pegadaian to continue to improve its competitiveness. The results of this study are in line with the results of research conducted by (Borolla, 2013) who found that the increase in credit disbursed will greatly affect the increase in profits Perum Pegadaian Branch of Ambon. The results are also in line with Setyasih (2006) who conducted a research to find out how much the effect of mortgage loans in increasing the income of Perum Pegadaian Kalibanteng Branch Office, which the result found that loans granted related to mortgage loans have a significant positive effect on earnings of mortgage which can further affect the net profit.

According to (Daengs, GS, et al., 2014), Financial statements are a reflection of the condition of a company in which there is information required by interested parties with the company.

Pegadaian as an organization has certain objectives that show a variety of 
things to do to meet the interested parties, including investors. Before deciding to invest in a particular, the investor must measure whether the objectives set by the company has been reached or not. However, this measurement is not easy to do because it's not just about the financial aspects but also non-financial of the company management. Measure of financial performance is only one way to find out whether a company has run operations in accordance with the plan or not, according to (Rizaldy, MR, et al., 2017).

\section{Acknowledgment}

This research is based on work supported by the Univerisity of 45 Surabaya, Indonesia the author thankfully colleagues from University of Islamic Bandung, Indonesia.

\section{Conclusion}

Number of active customers has an insignificant effect on net income in PT Pegadaian, There is significant and positive effect of operational office to increase net profit in PT Pegadaian, There is significant and positive effect of the amount of loans granted to net profit of PT Pegadaian, PT Pegadaian can always form a program that leads to customers involvement in investing or borrowing of mortgage money and facilitating public access to loans outside banks and is expected to be a financing solution, cutting off debt, avoid moneylenders and unfair loans.

PT Pegadaian is expected to remain focused on providing services to small micro business communities that are generally more resilient to slowing economic growth, It is expected that loans granted by PT Pegadaian must be higher, so that the achievement factor of profit as expected.

\section{References}

Borolla, JD, (2013). Pengaruh Tingkat Suku Bunga, Jumlah Nasabah dan Kredit Gadai Yang Disalurkan Terhadap Laba Bersih Perum Pegadaian Cabang Ambon, Skripsi FE Universitas Pattimura Ambon.

Daengs, Achmad, Mahjudin, Ririn, (2014). Pengaruh Earnings Management dan Level of Disclosure Terhadap Cost pf Equity Capital Pada Perusahaan Publik Sektor Industri Real Estate dan Property di Bursa Efek Indonesia, Jurnal Bina Ekonomi, Universitas Katholik Parahyangan
Bandung, Vol. 18, No. 1, Januari 2014, $43-68$.

Daengs, Achmad, Mahjudin, Eka, (2014). Cost of Quality Control to Improve Production Cost Efficiency and Sales Productivity, Jurnal The Indonesian Accounting Review, STIE Perbanas Surabaya, Vol. 4 No. 2, Juli 2014, 115-118.

Daengs GS, Achmad, (2018). Tax Planning Implementation On Income Tax, Article 23 as A Legal Effort To Minimize Tax Expense Payable. Jurnal Terapan Manajemen dan Bisnis, Vol. 4 No. 1, STKIP Singkawang, 1-9.

Eliana, Anis, 2009. Organizational Culture in the Successful Global Business, Majalah Ekonomi, Fakultas Ekonomi Bisnis Universitas Airlangga Surabaya, Vol. 19, No. 3, Desember 2009. 347 - 360.

Harahap, Syofyan Syafri, (2012). Analisis Kritis Terhadap Laporan Keuangan, Edisi Pertama Cetakan Keempat, PT Raja Grafindo Persada, Jakarta.

Harahap, Syofyan Syafri, (2016), Laporan Keuangan Tahunan PT Pegadaian, Jakarta.

Hermawan, Asep. (2013). Penelitian Bisnis Paradigma Kuantitatif. Jakarta: PT Grasindo

Mahjudin, Daengs, Achmad, (2017). Influential of Economic Growth, Manpower Absorption on Public Welfare, Jurnal Ekonomi dan Bisnis Optimum, Universitas Ahmad Dahlan, Yogyakarta, 14-26.

Riyanto, Bambang, (2013). Dasar-dasar Pembelanjaan Perusahaan, Edisi 4, BPFE, Yogyakarta.

Rizaldy, MR, Daengs, Achmad, (2017). Implementation of Economic Value Added and Market Value Added Analysis as Valuation Tools of Invest Feasibility, Jurnal Sinergi, Magister Management, UNITOMO, Surabaya, Vol. 7 No. 2, September, 6-15.

Sembiring. S, (2012). "Arti Penting Jaminan dalam Pemberian Kredit dalam Transaksi Bisnis Perbankan",Gloria Juris, Volume 7, nomor 1, Januari-April.

Setyasih. (2006). Pengaruh Kredit Gadai Terhadap Pendapatan Usaha Pada Perusahaan Umum Pegadaian Kantor Cabang Kalibanteng, Skripsi Fakultas Ekonomi Universitas Negeri Semarang.

Sugiono. (2014). Metode Penelitian Bisnis. Alfabeta. Bandung.

Suryanti, Dwi, (2006). Analisis Faktor-faktor Yang Mempengaruhi Besarnya Nilai Kredit Yang Diberikan Kepada Masyarakat Oleh Pegadaian Cabang Bantul 2003-2004, Skripsi Fakultas Ekonomi Universitas Wangsa Manggala Yogyakarta. 
MIMBAR, Vol.34 No 2 ${ }^{\text {nd }}$ (December) 2018 pp. 397-405

Susan Felda, Achmad Daengs, (2017).

Strategi Pemasaran Untuk Meningkatkan Penjualan Alat Kesehatan di UD. Putra Pratama Surabaya, Jurnal Pengabdian Masyarakat. Untag Surabaya. 14-23. 